\title{
Formation of Bushveld anorthosite by reactive porous flow
}

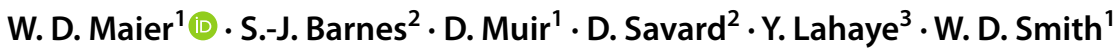

Received: 12 August 2020 / Accepted: 13 November 2020 / Published online: 23 December 2020

(c) The Author(s) 2020

\begin{abstract}
Bushveld anorthosites commonly contain the so-called "mottles" comprising irregular, typically centimetric domains of oikocrystic pyroxene or olivine enclosing small, embayed plagioclase grains. The mottles were traditionally interpreted to result from solidification of trapped intercumulus liquid or via in situ crystallisation at the top of the crystal mush. Here, we present microtextural and compositional data of a mottle to place further constraints on the formation of anorthosite layers. Element maps generated by scanning electron microscopy reveal that plagioclase within and around the mottle has markedly elevated $\mathrm{An}$ contents (up to $\mathrm{An}_{95}$ ) relative to the host anorthosite and is strongly reversely zoned. Other unusual features, some of which were reported previously, include a halo of sub-vertically oriented, acicular phlogopite around the mottle, elevated contents of disseminated sulfides, and relatively evolved yet Ni-rich olivine $\left(\mathrm{Fo}_{71-75}, 3000 \mathrm{ppm} \mathrm{Ni}\right)$. These features are interpreted to result from reactive porous flow of hot, acidic fluid enriched in nickel and sulfur through proto norite. The fluids dissolved mafic minerals and leached alkalis from the outer rims of plagioclase grains. Reconnaissance studies suggest that reversed zoning of plagioclase is a common feature in Bushveld norite and anorthosite. This implies that reactive porous flow could have been far more pervasive than currently realised and that Bushveld anorthosite layers formed through recrystallisation of norites.
\end{abstract}

Keywords Bushveld complex $\cdot$ Layered intrusions $\cdot$ Anorthosite $\cdot$ Reactive porous flow

\section{Introduction}

Petrologists have attempted to explain the formation of anorthosites ever since the seminal experiments by Bowen (1917) who showed that plagioclase normally crystallises cotectically with pyroxene or olivine. Bowen's proposed solution was that plagioclase and pyroxene have different settling velocities in basaltic magma, resulting in pyroxenitic and feldspathic cumulates. In massif-type anorthosites, a key problem with this model has been the apparent lack of

Communicated by Timothy L. Grove.

Supplementary Information The online version contains supplementary material available at https://doi.org/10.1007/s0041 0-020-01760-7.

W. D. Maier

maierw@cardiff.ac.uk

1 School of Earth and Ocean Sciences, Cardiff University, Cardiff, Wales, UK

2 Université du Québec à Chicoutimi, Chicoutimi, Canada

3 Geological Survey of Finland (GTK), Espoo, Finland voluminous complementary cumulates enriched in pyroxene or olivine. In the case of anorthosites in layered intrusions which are the focus of the present paper, the problem of the missing mafic minerals is less severe as there are usually abundant gabbroic and ultramafic cumulates associated with the anorthosite layers. However, some anorthosites in layered intrusions have seemingly intrusive relationships with their mafic-ultramafic host cumulates (Sonnenthal 1992; Meurer et al. 1997; Maier et al. 2016), suggesting that classical cumulate models are not always adequate to explain the anorthosites.

In the present paper, we report new microtextural and compositional evidence for recrystallisation of a sample of a Bushveld anorthosite layer. The rock contains irregular domains of cm-sized oikocrystic olivine surrounded by reaction rims and oikocrysts of orthopyroxene. Such domains are colloquially termed "mottles" in Bushveld literature. They are common in anorthosites of layered intrusions in general and have traditionally been explained by either crystallisation from trapped liquid (Wager et al. 1960) or from convecting magma at the top of the crystal pile (Campbell 1968; McBirney and Noyes 1979). Here, we present evidence to 
suggest that the mottles formed within the solidified cumulate pile, via reactive flow of acidic, alkali- and silica undersaturated fluid. We discuss the implications this has for the petrogenesis of Bushveld anorthosites.

\section{Geology of the Bushveld complex}

The Bushveld complex of South Africa is the world's largest layered intrusion comprising up to $8 \mathrm{~km}$ of layered cumulates exposed along a strike length of $\sim 400 \mathrm{~km}$ (Eales and Cawthorn 1996). The upper critical zone (UCZ) of the Bushveld complex consists of $\sim 500 \mathrm{~m}$ of interlayered mafic, ultramafic, and feldspathic rocks, forming mainly leuconorite, but also including orthopyroxenite, troctolite, harzburgite, several chromitite layers (Cameron 1982; Eales et al. 1990) and many layers of anorthosite. The world's richest and most extensively mined PGE reefs are located towards the top of the UCZ, namely the Merensky Reef, the UG2 chromitite, and the Platreef (Maier et al. 2013).

\section{The controversial origin of Bushveld anorthosite}

Despite a century of research, there is ongoing debate regarding the origin of anorthosite layers. The classical model of gravitational sorting involving plagioclase flotation (Wager and Brown 1967; Vermaak 1976; Raedeke and McCallum 1984; Eales et al. 1986; Irvine et al. 1998) competed with ideas interpreting anorthosites as (1) restites resulting from the flux of heat (via magma replenishments to the chamber, Eales et al. 1988; Mungall et al. 2016) or volatiles (via cumulate compaction or floor metamorphism, Sonnenthal 1992; Meurer et al. 1997; Baker and Boudreau 2019), (2) sill-like injections of feldspathic crystal mushes followed by draining or filter pressing of residual liquid (Maier et al. 2016), or (3) as precipitates from basaltic magma resulting from variations in pressure, either within the Bushveld chamber (Cawthorn and Ashwal 2009) or during trans-crustal magma ascent (Latypov et al. 2020).

None of these models can explain all features of all layered anorthosites, but to our mind, the model of Latypov et al. is particularly problematic. The authors performed polybaric crystallisation simulations using the MELTS program (Ghiorso and Sack 1995). As a starting liquid, the authors initially considered fine-grained Bushveld marginal rocks which are generally accepted to represent Bushveld parent magmas (Davies et al. 1980; Sharpe 1981; Barnes et al. 2010). Because this did not yield plagioclase alone on the liquidus during simulated magma ascent, they modified the major element composition of the basalt until the MELTS simulations showed significant plagioclase supersaturation. The hypothetical parent magma bears no resemblance to other Bushveld magmas or potential Al-rich parent magmas to massif anorthosites (Scoates and Mitchell 2000). While we accept that it is unlikely that all the magmas responsible for the Bushveld complex have been sampled in the sills, the approach taken by the authors is overly speculative in our minds. We also dispute that a relatively evolved and viscous magma can ascend through $30 \mathrm{~km}$ of crust without undergoing significant crystallisation, including plagioclase. Finally, if anorthosite layers in the Bushveld or other layered intrusions would have crystallised from plagioclase supersaturated melts, one would expect to find, in the periphery of the intrusions, plagioclase-phyric dolerites resembling the "Cat-rocks" that commonly occur in Archean greenstone belts (Ashwal 1993, and references therein), and possibly anorthosite dykes and sills.

\section{Sample location and analytical methods}

The analysed sample (IM841) is from a 10-m-thick mottled anorthosite layer that can be traced along most of the strike of the Bushveld complex (e.g., Gain 1985; Maier and Eales 1997; Maier et al. 2016). It was collected from drill core 1329 at Impala Wildebeestfontein mine, at a stratigraphic position approximately $15 \mathrm{~m}$ above the UG2 chromitite (Fig. 1) and initially characterised, using petrography and electron microprobe, by Maier (1995). In the present study, we additionally applied energy-dispersive X-ray spectroscopy using a field-emission scanning electron microscopy (FESEM, at Cardiff University) and laser ablation ICP-MS (at Université du Québec à Chicoutimi for major and trace elements, and the Geological Survey of Finland for Sr isotopes). All methods are described in Online Appendix 1.

\section{New results}

\section{Petrography and FESEM maps}

In the centre of the mottle is a $\sim 1$-cm-wide oikocryst of olivine (Figs. 2b, 3). It is relatively unaltered except for very thin $(\sim 10 \mu \mathrm{m})$ sub-vertical veinlets of serpentine with micrometric (up to $\sim 10 \mu \mathrm{m}$, Online Appendix 2) magnetite crystals, and trails of small $(<5 \mu \mathrm{m})$ fluid inclusions (Fig. 3c). The olivine also contains numerous inclusions of plagioclase, many of which are rounded or embayed, and some forming clusters (Fig. 3a). Olivine and plagioclase are strongly deformed. Olivine shows kink banding (Fig. 3a-c), while the plagioclase inclusions may show bent, spindleshaped deformation twin lamellae. Both minerals show pronounced undulous extinction. The inclusions tend to be surrounded by narrow symplectitic reaction rims consisting 


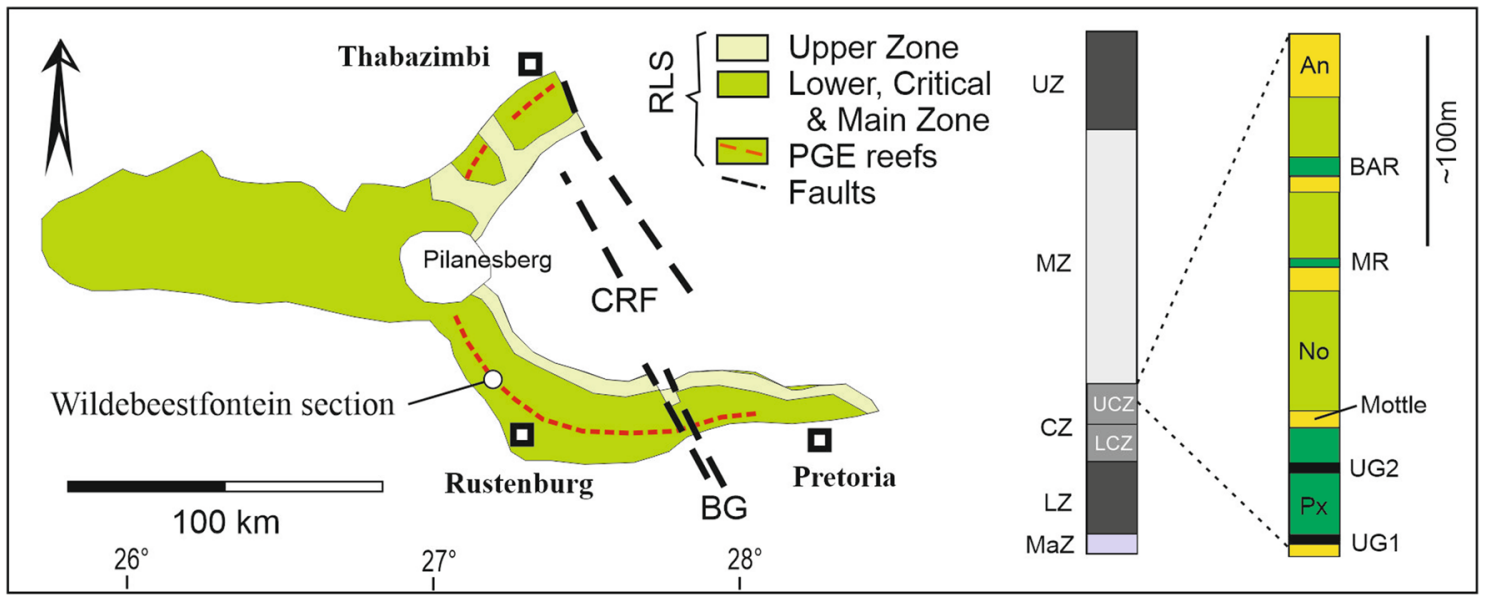

Fig. 1 Locality map of the western lobe of the Bushveld complex. $B G$ Brits graben, $C R F$ Crocodile River Fault, $R L S$ Rustenburg Layered Suite, $M a Z$ Marginal zone, $L Z$ Lower zone, $C Z$ Critical zone, $M Z$
Main zone, $U Z$ Upper zone, $B A R$ Bastard Reef, $M R$ Merensky Reef, $A n$ anorthosite, No norite, $P x$ pyroxenite

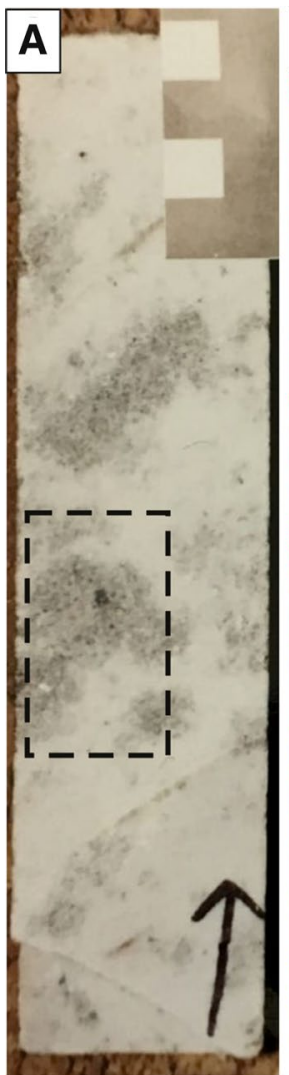

\section{B}

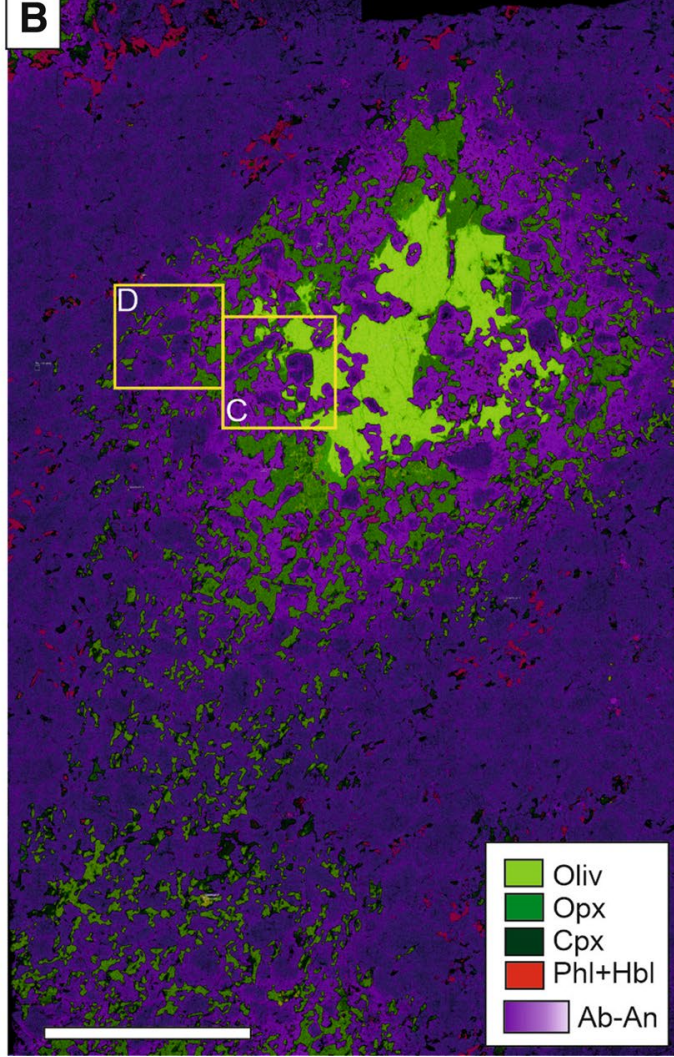

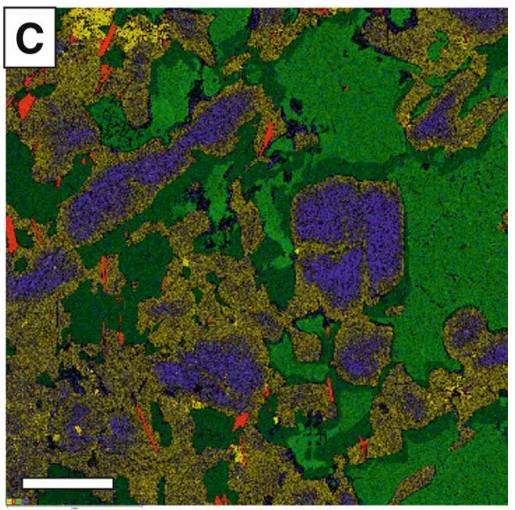

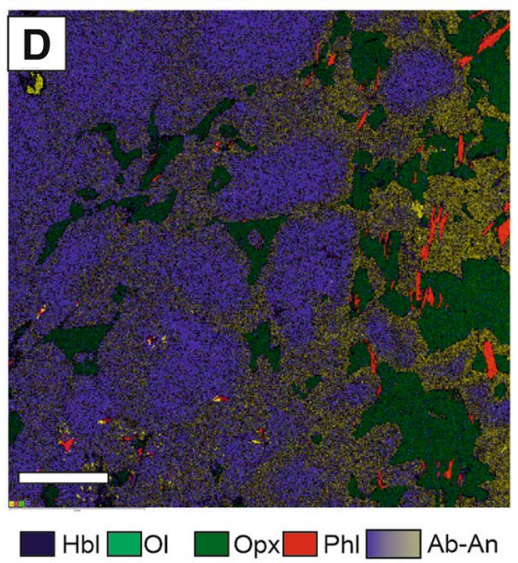

Fig. 2 a Image of drill core sample IM 841.5. The section analysed by FESEM is highlighted by the stippled box. b Element map of the mottle showing relatively calcic plagioclase forming a sub-circular domain around anhedral olivine oikocryst containing rounded inclusions of calcic plagioclase. The olivine oikocryst is surrounded by a noritic zone of intercumulus orthopyroxene and subhedral plagioclase. Host rock is anorthosite. Throughout the sample, plagioclase is reversed zoned, but this is particularly pronounced in the mottle. Also note edge of another high-An domain at the lower left of sample. c, d Close-ups from b. Note relatively calcic domains extending along the margin and cleavage planes of subhedral plagioclase (in c), and restriction of phlogopite to the most calcic domains (in d). Length of white bar in $\mathbf{b}$ is $1 \mathrm{~cm}$, and $0.1 \mathrm{~cm}$ in $\mathbf{c}$ and $\mathbf{d}$ 


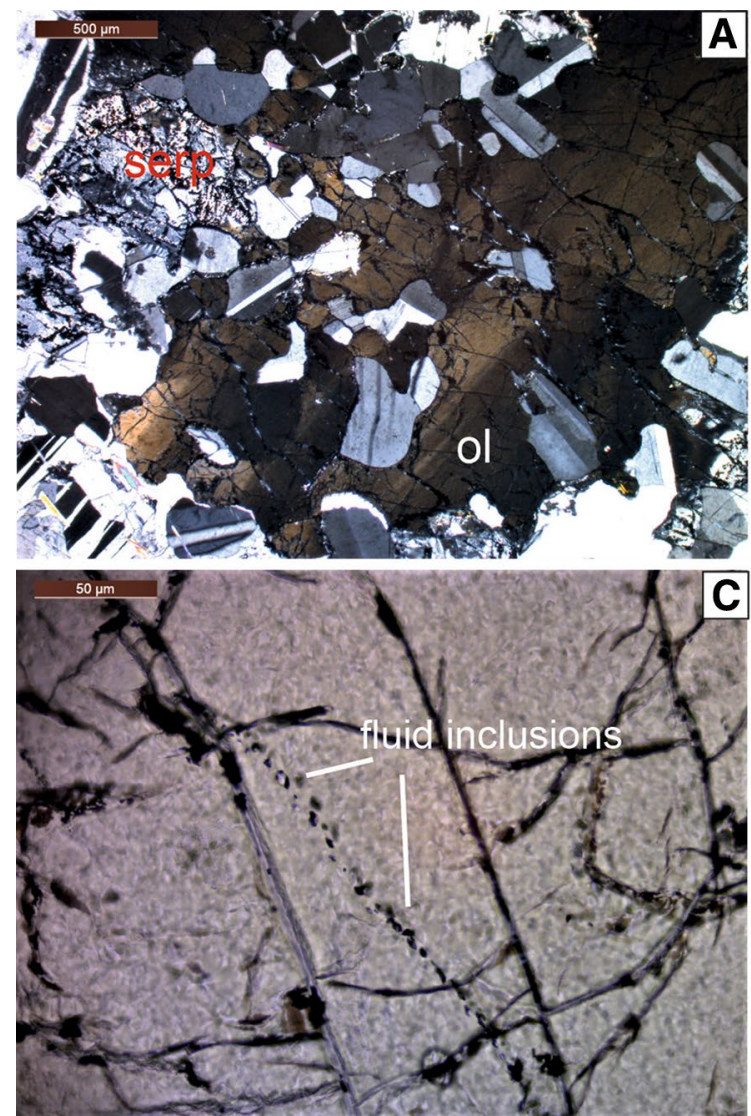

Fig. 3 Transmitted light photomicrographs of core zone of mottle. a, b Olivine oikocryst showing irregular, interpenetrative grain boundaries with plagioclase, undulose extinction, and kink banding. Also note embayed morphologies of plagioclase inclusions in olivine. c Fluid inclusion train in olivine of core zone. $\mathbf{d}$ Contact between nor-

typically of an inner zone of hercynite and augite, and an outer rim of magnetite and orthopyroxene (Online Appendix 2). Similar symplectites between olivine and plagioclase have previously been described from other layered intrusions (Ambler and Ashley 1977; Turner and Stüwe 1992; De Haas et al. 2002). The broadly troctolitic assemblage in the centre of the mottle is hereafter termed the "core zone".

The core zone is surrounded by a $\sim 1-\mathrm{cm}$-wide noritic zone consisting of reaction rims of orthopyroxene mantling olivine, oikocrystic orthopyroxene containing plagioclase inclusions with symplectitic rims (Online Appendix 3$)$, and some relatively small $(\sim 0.1 \mathrm{~mm})$ equant grains of orthopyroxene that may have annealed to form larger grains $(>1 \mathrm{~mm})$. The plagioclase in the noritic zone shows tapered deformation twins, undulous extinction, and highly irregular, interpenetrating grain boundaries. The noritic zone also contains numerous sub-vertically oriented bladed crystals of phlogopite that are $0.1-0.5 \mathrm{~mm}$ in length and mostly located at the contact between orthopyroxene and plagioclase (Fig. 2c, d, Online Appendix 4). In addition,

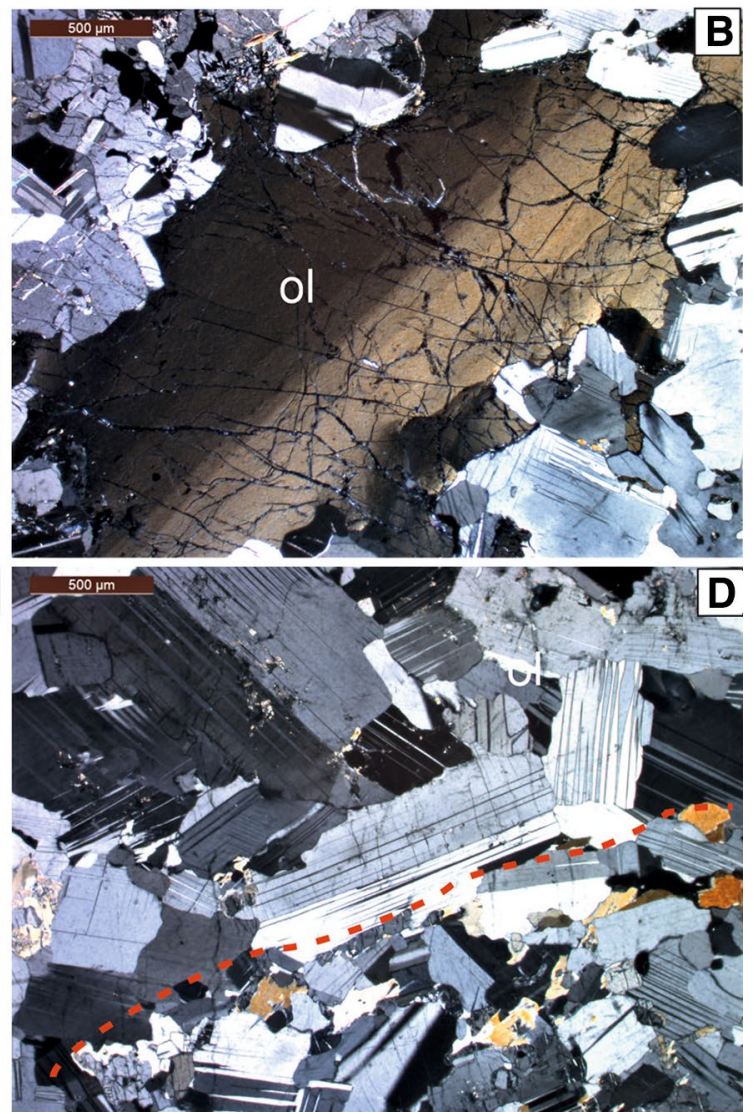

itic zone (lower right) and anorthositic host rock (upper left) defined by stippled line. Note larger grain size in host anorthosite. In both domains, plagioclase is strongly zoned, has highly irregular grain boundaries, and undulous extinction indicative of dynamic recrystallisation

there are relatively abundant (locally up to several modal $\%)$, small $(<10-50 \mu \mathrm{m})$ sulfide grains, comprising pyrrhotite and pentlandite, whereas chalcopyrite is totally absent (Online Appendix 3). During the lasering of the sample (see description below), we also observed a few incompatibleelement-rich accessory phases, likely titantite. Furthermore, the FESEM work revealed rare, very small $(<5 \mu \mathrm{m})$ grains of apatite (Online Appendix 3). Notably, the mottle is completely barren of quartz (Online Appendix 5).

The noritic zone is surrounded by monomineralic anorthosite. The boundary between the two domains is relatively sharp (Fig. 3d) with the host anorthosite being markedly coarser-grained than the noritic zone. Plagioclase grains are subhedral and show abundant evidence for dynamic recrystallisation, including undulous extinction, tapered and bent deformation twins, sub-grains, and fractured grains. Locally, the anorthosite contains interstitial subhedral grains of orthopyroxene and clinopyroxene which tend to be partially replaced by magnesian hornblende (Online Appendix 6). The anorthosite is almost barren of sulfide, 
containing just a few, very small $(<10 \mu \mathrm{m})$ isolated grains. The FESEM element maps indicate that the anorthosite contains rare quartz $(<<1 \%)$ (Online Appendix 7), forming small (typically $<100 \mu \mathrm{m}$ ) intercumulus grains or rare veinlets.

\section{Laser ablation ICP-MS data}

The concentrations of selected major and trace elements in plagioclase, olivine, orthopyroxene, clinopyroxene, phlogopite, and hornblende were determined by four laser ICP-MS traverses, complementing the microprobe data of Maier (1995). Online Appendix 8 shows the location of the 2 reconnaissance traverses, and Online Appendices 9 and 10 show the results for plagioclase and orthopyroxene in these traverses. Anorthite contents of plagioclase range from 75 to 95 , with a trend of decreasing values from the core zone through the noritic zone into the host anorthosite. Most but not all of the values above $\mathrm{An}_{90}$ occur in plagioclase inclusions within olivine of the core zone, resulting from a strong decrease in $\mathrm{Na}_{2} \mathrm{O}$ of plagioclase towards the core zone of the mottle (by a factor of 5, from 2.5 to $0.5 \mathrm{wt} \%$ ), and a decrease in $\mathrm{K}_{2} \mathrm{O}$ of plagioclase (by an order of magnitude from 0.1 to $0.01 \mathrm{wt} \%$ ). In contrast, $\mathrm{CaO}$ contents of plagioclase show relatively less variation, from mostly $\sim 15-16$ $\mathrm{wt} \%$ in the periphery to locally $\sim 19 \mathrm{wt} \%$ in the core zone. Trace elements in plagioclase may show significant variation, notably $\mathrm{Ba}$ (decreasing from $\sim 90 \mathrm{ppm}$ in the matrix to as little as $10 \mathrm{ppm}$ in the core zone), whereas most rare-earth elements (REE) show little detectable variation. Pronounced compositional variation across the sample is also seen in orthopyroxene, with both $\mathrm{Mg \#}$ and $\mathrm{Cr}$ decreasing progressively outwards, from Mg\# 78 to 68 (Online Appendix 10). Compared to the published mineral compositional data from the UCZ (which is strongly biased to core domains of minerals, Maier and Eales 1997), all main minerals of the mottle have unusual compositions, consistent with the electron microprobe data of Maier (1995). Thus, orthopyroxene in the noritic zone has relatively low $\mathrm{Cr}(0.05-0.25 \%$ vs $\left.0.2-0.4 \% \mathrm{Cr}_{2} \mathrm{O}_{3}\right)$ and $\mathrm{Ti}(<0.1-0.25$ vs up to $0.35 \mathrm{wt} \%$ $\mathrm{TiO}_{2}$ ), yet high $\mathrm{Al}\left(1.4-2\right.$ vs $\left.0.7-1.2 \mathrm{wt} \% \mathrm{Al}_{2} \mathrm{O}_{3}\right)$ and $\mathrm{Ni}$ (up to $>700$ vs $<500 \mathrm{ppm}$ in other UCZ orthopyroxene with similar $\mathrm{Mg \# ).} \mathrm{Olivine} \mathrm{has} \mathrm{relatively} \mathrm{high} \mathrm{NiO}(0.31-0.45$ wt\%) and low Fo (70-75) (Online Appendix 11), while showing no discernible zonation. Anorthite contents in plagioclase are as high as An95 (in the core zone) and 89 (in the noritic zone), whereas the host anorthosite adcumulate has An75-78, overlapping with the composition of core domains of typical UCZ cumulus plagioclase (Maier and Eales 1997). Details of the zoning patterns are shown in Fig. $2 c+d$, highlighting that the high-An domains not only rim the grains but also extend along what appear to be cleavage planes. Many of the most strongly reversely zoned grains are subhedral or euhedral, with little evidence for resorption.

In Fig. 4, we show an example of grain-scale mapping across a plagioclase grain and adjacent phlogopite and orthopyroxene in the noritic zone conducted during two high-resolution laser ablation ICP-MS traverses (see Online Appendix 12 for location of traverses). The data highlight the pronounced zonation of the plagioclase, with the core zone of the grain being relatively enriched in $\mathrm{Na}_{2} \mathrm{O}$ and $\mathrm{Ba}$ (as well as $\mathrm{Sr}$ and $\mathrm{Eu}$, not shown), whereas the margins are depleted in $\mathrm{Na}_{2} \mathrm{O}$ and $\mathrm{K}_{2} \mathrm{O}$. Laser ablation ICP-MS maps of selected parts of the mottle provided in Electronic Appendix 13-17 further show that the bulk of Ba and $\mathrm{K}$, as well as trace elements such as $\mathrm{Rb}, \mathrm{Ti}$, and $\mathrm{Li}$ are hosted in phlogopite, whereas most of the REE, Hf, Zr, and Y are hosted by accessory minerals (possibly titanite) associated with intergrowths of phlogopite and pyroxene distally located from the core zone.

Initial $\mathrm{Sr}$-isotopic ratios $\left({ }^{87} \mathrm{Sr} /{ }^{86} \mathrm{Sr}_{\mathrm{i}}\right)$ of plagioclase in the core zone and noritic zone as well as the host anorthosite are between 0.7061 and 0.7068 (Fig. 5, Online Appendix 18), in the typical range of the UG2-Merensky Reef interval of the WBC (Eales et al. 1990; Kruger 1994), and with a similar intra-sample range of values as observed in norites and anorthosites by Yang et al. (2013). Where several closely spaced analyses have been performed, they show significant compositional variation. For example, analyses at locality 7 vary between $\mathrm{Sr}_{\mathrm{i}} 0.7068$ and $0.7063( \pm 0.00007)$. The An contents of the $\mathrm{Sr}$ isotope sample spots are not available, but it is clear that the relatively high $\mathrm{Sr}_{i}$ values (above 0.70645) all come from plagioclase grains located peripheral to the mottle which tends to have lower An content, whereas most $\mathrm{Sr}$ isotope analyses of plagioclase grains from the high-An core zone of the mottle have relatively low $\mathrm{Sr}_{\mathrm{i}}(<0.70645)$.

\section{Summary of key observations}

\section{Reversed zonation and highly calcic composition of plagioclase}

Detailed zoning studies of plagioclase in the Bushveld complex remain surprisingly rare, but several past authors have reported reversed zoning of plagioclase (von Gruenewaldt 1979; Schiffries 1982; de Klerk 1992; Maier 1995; Maier and Eales 1997; Hayes et al. 2017; Robb and Mungall 2020). Maier and Eales (1997) analysed rim-to-rim traverses of 20 plagioclase grains (cumulus crystals and inclusions in pyroxene and olivine) in six samples across the UG2-Merensky Reef interval (thickness up to $200 \mathrm{~m}$ ) and found that $~ 90 \%$ of the grains are reversely zoned with core compositions typically at $\mathrm{An}_{72-78}$ and rim compositions reaching $\mathrm{An}_{88}$. 

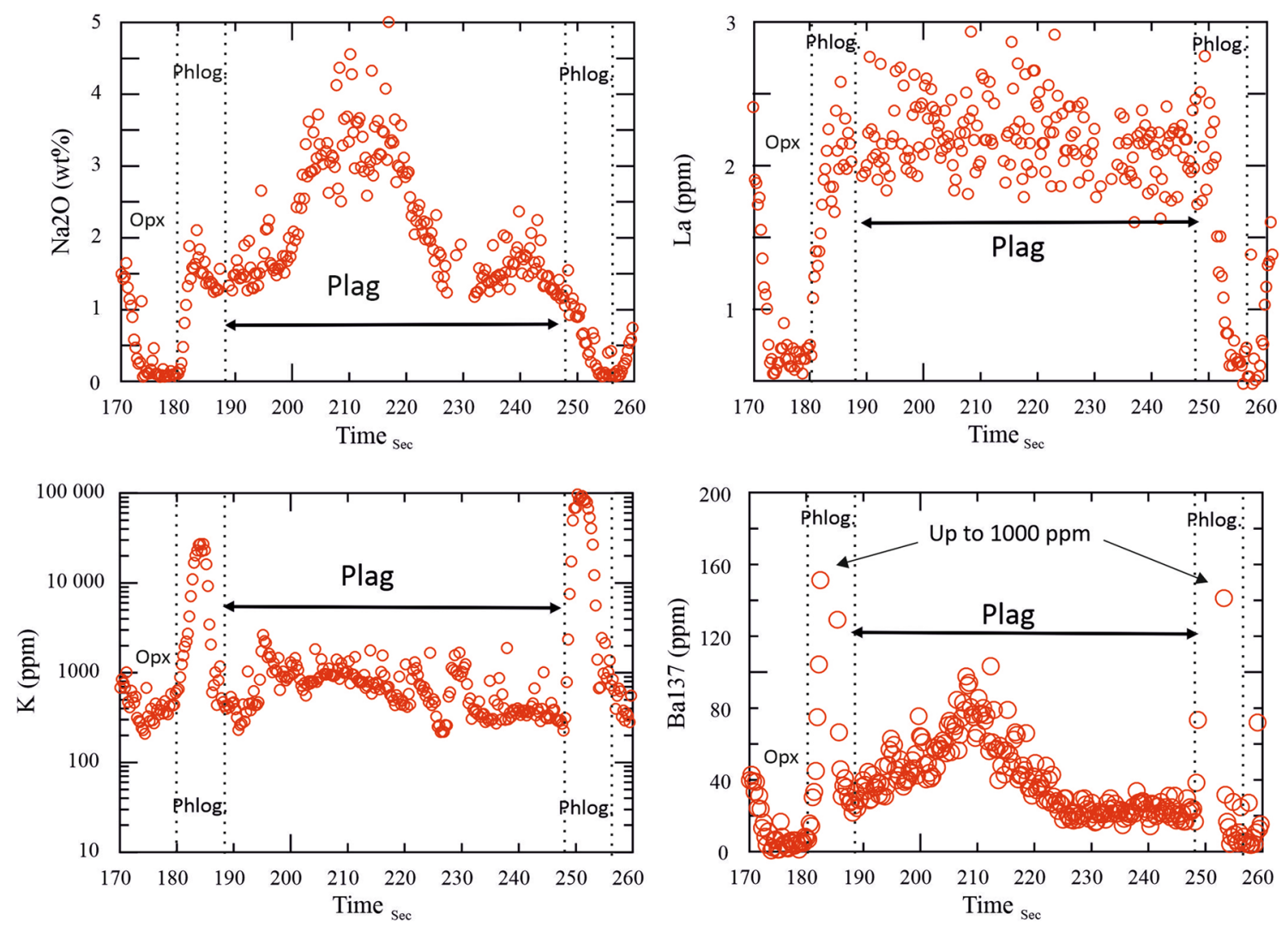

Fig. 4 Laser ablation ICP-MS profiles across a plagioclase grain and adjacent phlogopite and orthopyroxene in noritic zone of mottle. Length of profile $600 \mu \mathrm{m}$, step size $10 \mu \mathrm{m} / \mathrm{s}$

These results suggest that plagioclase in the uppermost UCZ is predominantly reversely zoned.

The present results are consistent with the earlier work, but they additionally show that reversed zoning is ubiquitous within individual samples, affecting most grains. A further important result is that the studied mottle shows higher An contents than the UCZ samples studied by Maier and Eales (1997) which could suggest that the mottle is highly unusual. However, despite a total of $\sim 1500$ analysed grains in 250 samples, the Maier and Eales study was essentially a reconnaissance study focussing on core domains of cumulus plagioclase ( $\sim 5$ grains per sample, typically several metres stratigraphic distance between samples). Many of their most calcic compositions are from anorthosites or olivine-bearing rocks (ol-norites, troctolites, and harzburgites). We expect that future studies examining other mottles and olivinebearing lithologies, and focussing on plagioclase zonation will reveal that highly calcic plagioclase $(\mathrm{An}>90)$ is much more common than currently recognised (e.g., Scoon and Costin 2018).

The ubiquity of the reversed zoning across the studied sample (Fig. 2b), together with the discordant nature of the high-Ca/low-Na domain constituting the core and noritic zones, suggests that the sample was pervasively percolated by a post-cumulus reactive agent removing $\mathrm{Na}$. The presence of highly calcic domains around euhedral crystals and along cleavage planes of plagioclase grains suggests that the reactive agent was a fluid, leaching alkalis, rather than a melt causing partial resorption of grains. The precise composition of the fluid remains currently unknown, but evidence from previous fluid and melt inclusion studies in the UCZ (Ballhaus and Stumpfl 1986; Li et al. 2004; Zhitova et al. 2016) suggests that $\mathrm{UCZ}$ fluids were enriched in $\mathrm{H}_{2} \mathrm{O}, \mathrm{Cl}$, $\mathrm{CO}_{2}$, and $\mathrm{CH}_{4}$. Furthermore, the near total absence of quartz in the mottle and its host anorthosite suggests that the fluid was Si undersaturated (see discussion below).

\section{Abundance of phlogopite and symplectite}

Magmatic phlogopite is normally considered to be a rare phase in the lower and central portions of the Bushveld complex (i.e., the lower, critical, and main zones). For example, Teigler and Eales (1996) found < 1\% phlogopite in most rocks of the Lower and Critical zones. The apparent scarcity of phlogopite led many previous authors to suggest that Bushveld magmas were essentially anhydrous or contained little water (e.g., Barnes et al. 2010), and to question an important role for metasomatism in cumulate 

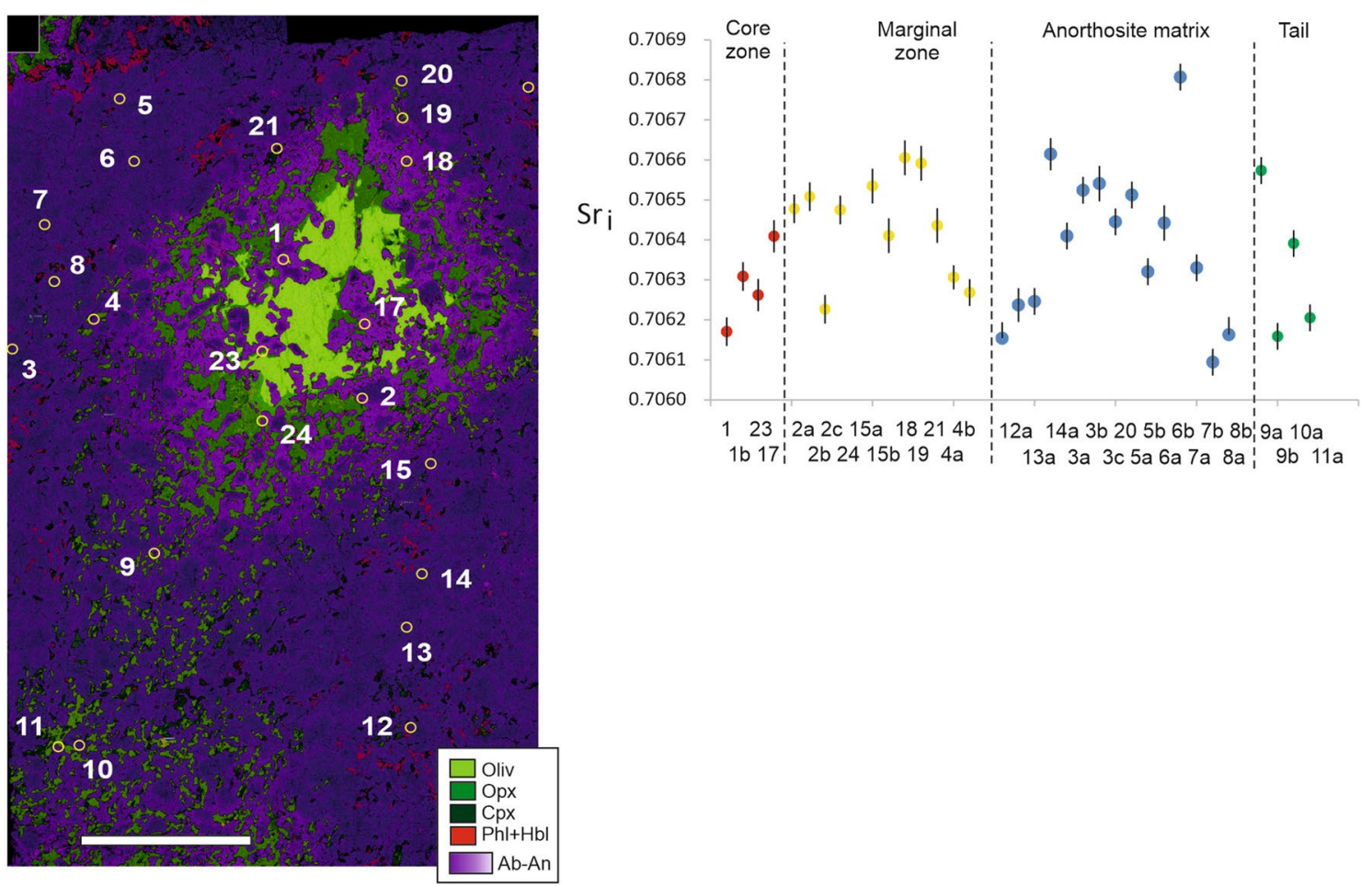

Fig. 5 Initial $\mathrm{Sr}$ isotope ratios in analysed mottle. Length of white bar is $1 \mathrm{~cm}$. Error bars denote $2 \sigma$ variation. See Online Appendix 13 for complete data

formation (Cawthorn and Ashwal 2005). The present study shows that phlogopite may be locally abundant in the UCZ. Its spatial association with orthopyroxene-magnetite-hercynite-augite symplectites suggests that this assemblage formed in response to sub-solidus reaction between olivine and plagioclase in the presence of volatiles (de Haas et al. 2002, and references therein). The sub-vertical orientation of phlogopite, coinciding with the orientation of most serpentine veins in the olivine oikocryst, could reflect a fabric imposed during late- or post-magmatic compaction of the cumulates.

\section{Paucity of quartz}

The total absence of interstitial quartz from the mottle (Online Appendix 5) and the paucity of quartz in the anorthositic host rock (Online Appendix 7) is unusual compared to some other UCZ rocks (e.g., Holness et al. 2017) and anorthosites in the Stillwater complex (Salpas et al. 1983) where quartz may constitute up to a few percent of the rock and is thought to have crystallised from trapped liquid. The absence of quartz in the mottle thus suggests that primary quartz was removed during crystallisation.

\section{Sr isotopes}

The variability of the $\mathrm{Sr}$ isotope signatures of plagioclase in the analysed sample is consistent with percolation of a reactive agent (Hepworth et al. 2020). The compositional overlap of the data with those of previous studies of the UCZ (Yang et al. 2013) could suggest that the reactive agent was derived from within the Bushveld cumulate pile. However, it should be noted that $\mathrm{Sr}$ isotope data on the sedimentary floor rocks remain scarce, and the few data on the dolomitic Transvaal floor rocks indicate $\mathrm{Sr}_{\mathrm{i}} 0.7040-0.7057$, in the range of the cumulates (Pronost et al. 2008; Abernethy 2020).

\section{Composition of olivine and orthopyroxene}

The association of oikocrystic olivine containing embayed, highly calcic plagioclase inclusions, all being hosted in a discordant, pod-like domain of reversely zoned, high-anorthosite plagioclase is consistent with selective recrystallisation in response to a reactive agent percolating through a feldspathic proto cumulate within which orthopyroxene was replaced by olivine (Schiffries 1982):

$$
2\left(\mathrm{Mg}_{(1-x)}, \mathrm{Fe}_{x}\right) \mathrm{SiO}_{3}=\left(\mathrm{Mg}_{(1-x)}, \mathrm{Fe}_{x}\right) 2 \mathrm{SiO}_{4}+\mathrm{SiO}_{2(\mathrm{aq})} \text {. }
$$


The nickel enrichment of the olivine and pyroxene suggests that the reactive agent was enriched in Ni. Holwell et al. (2017) have demonstrated that the metal can be mobile if Ni-bearing sulfides are completely dissolved by percolating late-magmatic fluids, and Scholten et al. (2018) have shown that Ni may be particularly mobile in acidic fluids. A potential source rock for the $\mathrm{Ni}$ - and S-rich fluids could be the PGE-rich, yet sulfide-poor UG2 chromitite layer located some $15 \mathrm{~m}$ below the analysed mottle. The paucity in sulfide of that layer was previously proposed to have resulted from late-magmatic S loss to a percolating fluid ( $\mathrm{Li}$ et al. 2004).

\section{Models for the formation of the mottle}

\section{Crystallisation of trapped melt}

Wager et al. (1960) showed that oikocrysts may form from residual silicate melt trapped within the solidifying and compacting cumulate pile, thereby resulting in orthocumulates or mesocumulates. One would expect that this process ultimately leads to supersaturation of the trapped melt in $\mathrm{H}_{2} \mathrm{O}$, a lowering of the solidus of the assemblage and partial eutectic melting of the cumulate and preferential dissolution of albite component along the margins of plagioclase (Adams 1968; Johannes 1978): mottle. Eutectic melting of norite containing plagioclase and pyroxene in cotectic proportions would not generate anorthosite or leuconorite. (2) In a scenario of trapped melt crystallisation, one would expect local enrichment in incompatible trace elements and residual phases such as quartz, alkali feldspar, albite, hydrous phases (mica and amphibole), and trace minerals. Apart from potential titanite and zircon as well as rare apatite, few of these have been identified in the present mottle. Phlogopite is abundant, but likely represents a sub-solidus product of the reaction between olivine and orthopyroxene with plagioclase. (3) Robb and Mungall (2020) argued that plagioclase zonation would not have been preserved in large magma chambers undergoing prolonged cooling, due to diffusive re-equilibration. They went on to suggest that the zoned plagioclase crystals of the UCZ reflect rapid cooling from magmatic emplacement temperatures to the $\mathrm{CaAl}-\mathrm{NaSi}$ exchange closure temperature of plagioclase $\left(879^{\circ} \mathrm{C}\right.$; Robb and Mungall 2020), which they proposed resulted from the emplacement of relatively narrow sills into a largely solidified cumulate package. However, this model cannot be applied to the present mottle which is located within a thick anorthosite, $7 \mathrm{~m}$ above the top contact of the UG2 pyroxenite. Furthermore, the sill model is inconsistent with the ubiquity of reversed zoning throughout the largely noritic UG2-Merensky Reef interval (Maier and Eales 1997).

$2 \mathrm{Na}_{0.5} \mathrm{Ca}_{0.5} \mathrm{Al}_{1.5} \mathrm{Si}_{2.5} \mathrm{O}_{8}+6 \mathrm{H}_{2} \mathrm{O}=\mathrm{CaAl}_{2} \mathrm{Si}_{2} \mathrm{O}_{8}+\mathrm{Na}_{(\mathrm{aq})}^{+}+\mathrm{AlO}_{(\mathrm{aq})}^{2-}+3 \mathrm{H}_{4} \mathrm{SiO}_{4(\mathrm{aq})}$.

If trapped melt pockets were hosted by anorthosite or leuconorite, as in the studied mottle, eutectic melting may lead to complete dissolution of all mafic minerals and, in the case of efficient draining of the partial melt, to nearmonomineralic anorthosite (Online Appendix 19). In contrast, where the melt was trapped, it would recrystallise to form mafic mottles. The addition of water to basalt causes an enlargement of the stability field of olivine, and a reduction of that of plagioclase (Sisson and Grove 1993; Mathez and Kinzler 2017). Thus, the first phase to crystallise in the melt pocket might be olivine enclosing small, partially resorbed, highly calcic, and reversely zoned plagioclase grains. During continued crystallisation of the melt pocket, the olivine would react peritectically to pyroxene. Where some of the residual hydrous, eutectic melt could escape prior to complete solidification of mottles, oikocrystic olivine was preserved (Boudreau 1988). The final steps were the formation of phlogopite by reaction between pyroxene and plagioclase, hornblende by alteration of clinopyroxene, serpentine by alteration of olivine, and symplectites between olivine and plagioclase, all triggered by residual hydrous fluid.

However, there are several problems with the model: (1) it is unclear how the anorthosite formed that hosts the

\section{Grain coarsening}

Working on the Lac St. Jean anorthosite of Quebec, Higgins (1998) suggested that, to minimise the free energy of a troctolitic crystal mush, plagioclase and olivine grains underwent coarsening, resulting from dissolution of small crystals and growth of larger crystals. This could be a selforganising feedback process of the type that produces inch-scale layering (Boudreau 1994), operating by diffusion in the trapped liquid film rather than physical migration of liquid. It could contribute to the formation of calcic rims of plagioclase by preferentially dissolving the calcic cores of small, kinetically unstable plagioclase crystals and resulting in plagioclase being partially dissolved in relatively olivine-rich areas and recrystallized in plagioclase-rich domains, and producing a bimodal assemblage of anorthosite and melatroctolite. Maier (1995, Fig. 8) has shown that small plagioclase grains in anorthosite can be highly enriched in An content relative to neighbouring large grains, consistent with the model of Higgins (1998). However, as in model (1), there is the potential problem of diffusive re-equilibration obliterating any magmatic plagioclase zonation (Robb and Mungall 2020). 


\section{Reactive percolative flow}

In this model, solid norite was percolated by acidic fluids derived from the cooling and solidifying footwall rocks (Fig. 6a). Because silica saturation is positively correlated to temperature, particularly at elevated $\mathrm{NaCl}$ content (Manning

$$
2 \mathrm{H}_{2} \mathrm{O}+\mathrm{Mg}_{2} \mathrm{Si}_{2} \mathrm{O}_{6}=\mathrm{H}_{4} \mathrm{SiO}_{4}+\mathrm{Mg}_{2} \mathrm{SiO}_{4} \text {. }
$$

Higher fluid/rock ratios may result in the loss of all mafic phases. Due to the acidity of the fluids, alkalis are leached from the margins of plagioclase grains (Schiffries 1982) resulting in reversely zoned plagioclase:

$\mathrm{H}^{+}+2 \mathrm{H}_{2} \mathrm{O}+(\mathrm{Ca}, \mathrm{Na})(\mathrm{Al}, \mathrm{Si})\left(\mathrm{AlSi}_{2} \mathrm{O}_{8}\right)=\mathrm{Na}^{+}+\mathrm{H}_{4} \mathrm{SiO}_{4}+\mathrm{CaAl}_{2} \mathrm{Si}_{2} \mathrm{O}_{8}$

1994; Newton and Manning 2000), fluids ascending from relatively cool footwall cumulates into hotter rocks near the top of the cumulate pile become undersaturated in $\mathrm{SiO}_{2}$, triggering incongruent dissolution of pyroxene, and crystallisation of olivine (Fig. 6b) (Meurer et al. 1997; Baker and Boudreau 2019):
This model would potentially offer an explanation for the preservation of the plagioclase zonation in the UCZ without invoking thin sills (Mungall et al. 2016) as the late-magmatic fluids may have had a temperature near the CaAl-NaSi closure temperature of plagioclase $\left(879{ }^{\circ} \mathrm{C}\right.$; Robb and Mungall 2020).
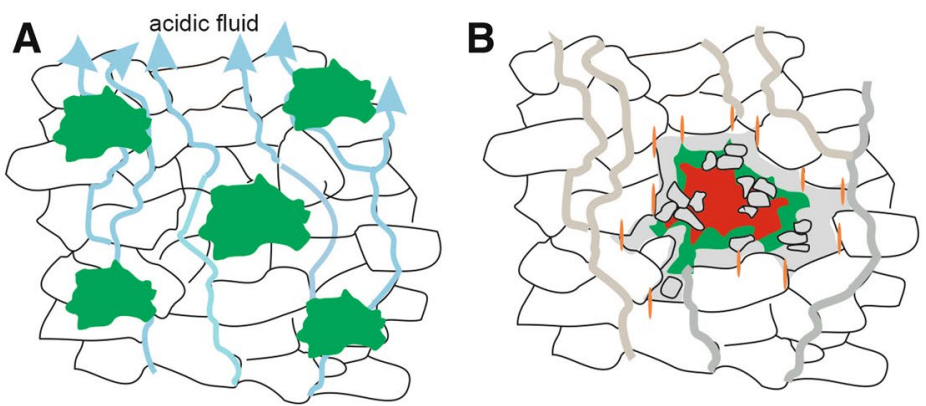

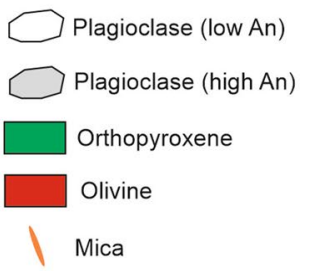

is rimmed by peritectic reaction orthopyroxene and surrounded by a corona of high-An plagioclase. The channelised fluid caused a network of reversely zoned plagioclase in the host anorthosite. See text for further explanation
Fig. 7 Underground exposures of anorthosite in UCZ. a Corona horizon, Union section of WBC (photograph reproduced from de Klerk 1982). b Incipient formation of anorthosite above Pseudoreef, Amandelbult section of WBC
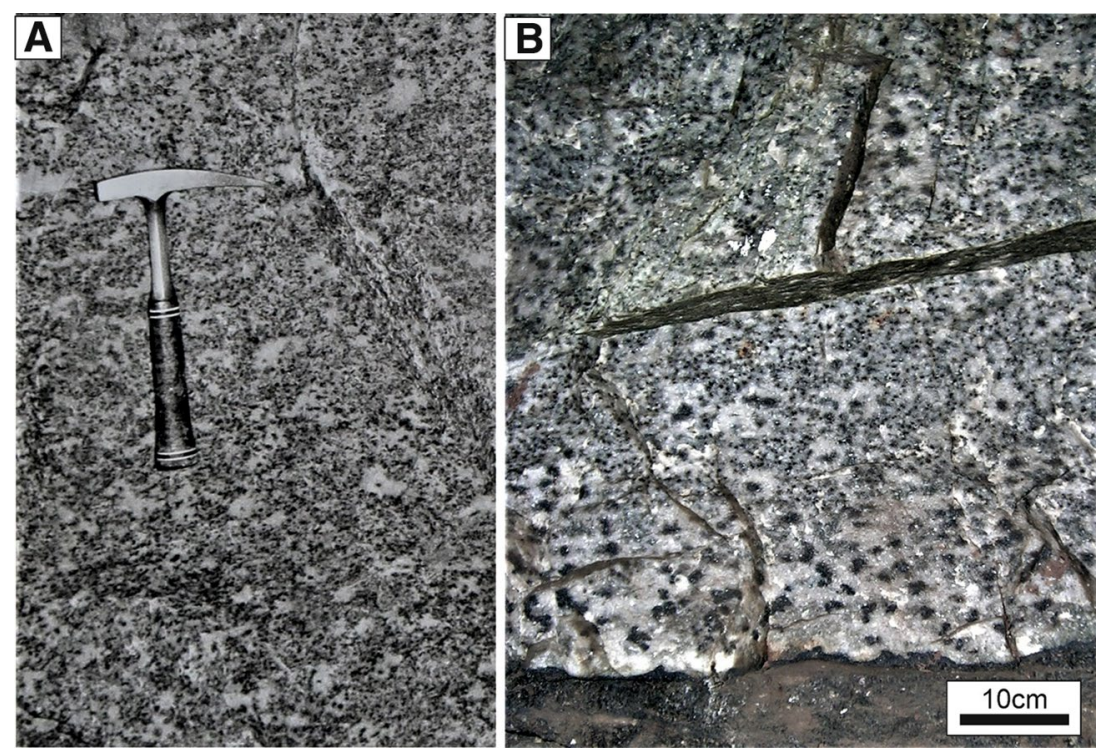

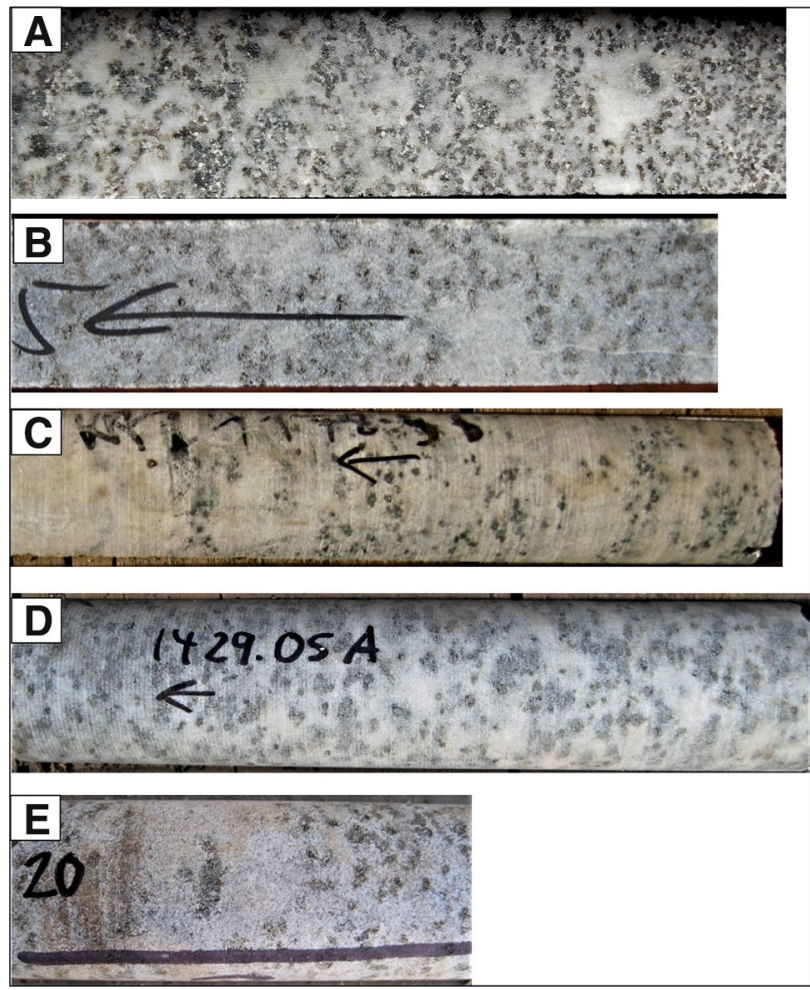

Fig. 8 Corona structures in the UG2-Merensky Reef interval of the Bushveld Upper Critical Zone. In all images, stratigraphic up is to the left. Width of drill cores is $4.76 \mathrm{~cm}$. a Flatreef, farm Turfspruit, directly below Merensky Reef. b Impala mine, $100 \mathrm{~m}$ above UG2 chromitite, sample IS-97.5. c Brits graben, Boulder Bed horizon, $30 \mathrm{~m}$ below Merensky Reef, sample KR2-1178. d Wolhuterskop, $35 \mathrm{~m}$ below Merensky Reef, sample LK7-1429.05. e Union Section, 7 m below Merensky Reef, sample B235-20

\section{The broader context: formation of Bushveld anorthosites}

Leuconorites in the uppermost UCZ tend to contain cmsized, sub-circular anorthositic domains often featuring cores of pyroxene or, less commonly, olivine (Figs. 7, 8). The structures were first described from the Merensky footwall unit in underground tunnels at a platinum mine at Union Section, northwestern Bushveld, by de Klerk (1982) who termed them corona structures (Fig. 7a). At Union Section, they are directly overlain by a mottled anorthosite layer, possibly suggesting that corona structures and anorthosite layers represent different stages of a process involving removal of pyroxene from norite. A key exposure from Amandelbult Section supporting this model is shown in Fig. 7b. Here, harzburgite is overlain by mottled anorthosite which progressively grades into leuconorite containing corona textures in places.

Analogous to the mottle studied in detail in the present paper, the corona structures lack evolved minerals such as quartz or alkali feldspar, and thus, there is no evidence for the presence of residual melt. Instead, their origin can be more readily understood in the context of the model of fluid dissolution applied by Schiffries (1982) to Bushveld hortonolite pipes, by Meurer et al. (1997) to Stillwater troctolites, and by the present authors to the formation of the mottle, as discussed above. That is, the dissolution of mafic minerals and the leaching of alkalis from plagioclase by relatively cold, Si undersaturated acidic fluids ascending through the solidifying crystal pile. Where the "pregnant" fluids continued their ascent they left behind anorthositic restite. Where the fluids mixed with cooler fluids from below, notably in the fluid conduits, pyroxene or olivine reprecipitated. The corona structures with their mafic cores within restitic anorthosite could represent miniature analogues of the ultramafic pipes. The mottle studied in the present paper could represent an advanced stage in the dissolution process after most of the proto norite has been transformed to anorthosite.

The implication of the model is that Bushveld anorthosite layers formed as a result of percolative flow of a reactive fluid through norite. The initial stage was the development of discordant pods of anorthosite (i.e., the corona structures). Prolonged flux of fluids, possibly focussed along layer contacts, resulted in larger pods and ultimately the formation of anorthosite layers (Fig. 7b). The model is consistent with the similarity in the composition of plagioclase from UCZ norites and anorthosites. There is no indication that anorthosite layers formed from melts supersaturated in plagioclase as suggested by Latypov et al. (2020), or represent restites resulting from injection of sills of mafic or ultramafic melts or crystal mushes as suggested by Mungall et al. (2016).

\section{Summary and conclusions}

$\mathrm{X}$-ray element mapping provides a powerful tool to unravel the crystallisation history of layered intrusions, notably the formation of the enigmatic anorthosite layers. In the present study, we mapped a so-called "mottle" consisting of a pocket of anhedral olivine and orthopyroxene within anorthosite. Laser ablation ICP-MS data reveal that all main minerals have unusual compositions compared to the host rocks; olivine in the core of the mottle is relatively evolved yet $\mathrm{Ni}$-rich, hosting plagioclase inclusions with unusually high-An contents (up to $A n_{95}$ ). The core of the mottle is surrounded by a fringe of strongly reversed zoned, relatively calcic plagioclase (up to $\mathrm{An}_{89}$ ), unusually $\mathrm{Al}$ - and $\mathrm{Ni}$-enriched, yet $\mathrm{Cr}$ - and Ti-depleted orthopyroxene, abundant phlogopite, elevated sulfide content as well as rare incompatible trace element-rich trace phases likely including titanite. These features cannot be explained by classical cumulus models. Instead, the present data suggest 
that the anorthosite recrystallised in response to reactive percolative flow of a fluid that preferentially leached mafic minerals from proto norite. It is suggested that anorthosite layers in general formed through reactive percolative flow and recrystallisation of norite to anorthosite.

Acknowledgements We would like to thank Impala Platinum Mines for access to their properties and provision of the samples. Discussions with Ed Mathez, Steve Barnes, Johan Lissenberg, Jon Blundy, Jim Mungall, and Alan Boudreau helped to clarify our understanding of reactive porous flow.

Open Access This article is licensed under a Creative Commons Attribution 4.0 International License, which permits use, sharing, adaptation, distribution and reproduction in any medium or format, as long as you give appropriate credit to the original author(s) and the source, provide a link to the Creative Commons licence, and indicate if changes were made. The images or other third party material in this article are included in the article's Creative Commons licence, unless indicated otherwise in a credit line to the material. If material is not included in the article's Creative Commons licence and your intended use is not permitted by statutory regulation or exceeds the permitted use, you will need to obtain permission directly from the copyright holder. To view a copy of this licence, visit http://creativecommons.org/licenses/by/4.0/.

\section{References}

Abernethy KE (2020) Assimilation of dolomite by Bushveld magmas in the Flatreef; implications for the origin of Ni-Cu-PGE mineralization and the precambrian atmosphere. Cardiff University, $\mathrm{Ph} . \mathrm{D}$. thesis (unpublished)

Adams JB (1968) Differential solution of plagioclase in supercritical water. Am Mineral J Earth Planet Mater 53:1603-1613

Ambler EP, Ashley PM (1977) Vermicular orthopyroxene-magnetite symplectites from the Wateranga layered mafic intrusion, Queensland, Australia. Lithos 10:163-172

Ashwal LD (1993) Anorthosites. Springer, Berlin, p 422

Baker SR, Boudreau AE (2019) The influence of the thick banded series anorthosites on the crystallization of the surrounding rock of the Stillwater complex, Montana. Contrib Mineral Petrol 174:99. https://doi.org/10.1007/s00410-019-1635-x

Ballhaus CG, Stumpfl EF (1986) Sulfide and platinum mineralization in the Merensky Reef: evidence from hydrous silicates and fluid inclusions. Contrib Mineral Petrol 94:93-204

Barnes S-J, Maier WD, Curl E (2010) Composition of the marginal rocks and sills of the Rustenburg layered suite, Bushveld complex, South Africa: implications for the formation of the PGE deposits. Econ Geol 105:1491-1511

Boudreau AE (1988) Investigations of the stillwater complex IV. The role of volatiles in the petrogenesis of the J-M Reef, Minneapolis Adit section. Can Mineral 26:93-208

Boudreau AE (1994) Pattern formation during crystallisation in two crystal, two component systems. S Afr J Geol 97:473-485

Bowen NL (1917) The problem of the anorthosites. J Geol 25:209-243

Cameron EN (1982) The upper critical zone of the eastern Bushveld complex-precursor of the Merensky Reef. Econ Geol 77:1307-1327

Campbell IH (1968) The origin of heteradcumulate and adcumulate textures in the Jimberlana Norite. Geol Mag 105:378-383

Cawthorn RG, Ashwal LD (2009) Origin of anorthosite and magnetitite layers in the Bushveld Complex, constrained by major element compositions of plagioclase. J Petrol 50:1607-1637
Davies G, Cawthorn RG, Barton JM, Morton M (1980) Parental magma to the Bushveld complex. Nature 287:33-35

de Haas GJL, Nijland TG, Valbracht PJ, Maijer C, Verschure R, Andersen T (2002) Magmatic versus metamorphic origin of olivine-plagioclase coronas. Contrib Mineral Petrol 143:537-550

De Klerk WJ (1982) The geology, geochemistry and silicate mineralogy of the upper critical zone of the north-western Bushveld complex, at Rustenburg Platinum Mines, Union Section. Rhodes University, MSc thesis (unpublished)

De Klerk WJ (1992) Petrogenesis of the upper critical zone of the Western Bushveld complex with emphasis on the UG1 footwall and Bastard Units. Ph.D. thesis, Rhodes University, Grahamstown

Eales HV, Cawthorn RG (1996) The Bushveld complex. In: Cawthorn RG (ed) Layered intrusions. Elsevier, New York, pp 181-229

Eales HV, Marsh JS, Mitchell AA, De Klerk WJ, Kruger FJ, Field M (1986) Some geochemical constraints upon models for the crystallization of the upper critical zone-main zone interval, northwestern Bushveld complex. Mineral Mag 50:567-582

Eales HV, Field M, De Klerk WJ, Scoon RN (1988) Regional trends of chemical variation and thermal erosion in the upper critical zone, western Bushveld complex. Mineral Mag 52:63-79

Eales HV, De Klerk WJ, Teigler B (1990) Evidence for magma mixing processes within the critical and lower zones of the northwestern Bushveld complex, South Africa. Chem Geol 88:261-278

Gain SB (1985) The geologic setting of the platiniferous UG2 chromitite layer on Maandagshoek, eastern Bushveld complex. Econ Geol 80:925-943

Ghiorso MS, Sack RO (1995) Chemical mass transfer in magmatic processes IV. A revised and internally consistent thermodynamic model for the interpolation and extrapolation of liquid-solid equilibria in magmatic systems at elevated temperatures and pressures. Contrib Mineral Petrol 119:197-212

Hayes B, Ashwal LD, Webb SJ, Bybee GM (2017) Large-scale magmatic layering in the main zone of the Bushveld complex and episodic downward magma infiltration. Contrib Mineral Petrol 172(2-3): 13

Hepworth LN, Daly JS, Gertisser R, Johnson CG, Emeleus CH, O'Driscoll B (2020) Rapid crystallization of precious-metalmineralized layers in mafic magmatic systems. Nat Geosci $13: 375-381$

Higgins MD (1998) Origin of anorthosite by textural coarsening: quantitative measurements of a natural sequence of textural development. J Petrol 39:1307-1323

Holness MB, Cawthorn RG, Roberts J (2017) The thickness of the crystal mush on the floor of the Bushveld magma chamber. Contrib Miner Petrol 172:102

Holwell DA, Adeyemi Z, Ward LA, Smith DJ, Graham SD, McDonald I, Smith JW (2017) Low temperature alteration of magmatic $\mathrm{Ni}-\mathrm{Cu}-\mathrm{PGE}$ sulfides as a source for hydrothermal Ni and PGE ores: a quantitative approach using automated mineralogy. Ore Geol Rev 91:718-740

Irvine TN, Andersen JCO, Brooks CK (1998) Included blocks (and blocks within blocks) in the Skaergaard intrusion: geological relations and the origins of rhythmic modally graded layers. Bull Geol Soc Am 110:1398-1447

Johannes W (1978) Melting of plagioclase in the system Ab-An- $\mathrm{H}_{2} \mathrm{O}$ and $\mathrm{Qz}-\mathrm{Ab}-\mathrm{An}-\mathrm{H}_{2} \mathrm{O}$ at $\mathrm{PH}_{2} \mathrm{O}=5 \mathrm{kbars}$, an equilibrium problem. Contrib Mineral Petrol 66:295-303

Kruger FJ (1994) The Sr-isotopic stratigraphy of the western Bushveld complex. S Afr J Geol 97:393-398

Latypov R, Chistyakova S, Costin G, Namur O, Barnes S, Kruger W (2020) Monomineralic anorthosites in layered intrusions are indicators of the magma chamber replenishment by plagioclase-onlysaturated melts. Sci Rep 10:1-14

Li C, Ripley EM, Merino E, Maier WD (2004) Replacement of base metal sulfides by actinolite, epidote, calcite, and magnetite in the 
UG2 and Merensky Reef of the Bushveld Complex, South Africa. Econ Geol 99:173-184

Maier WD (1995) Olivine oikocrysts in Bushveld anorthosite: some implications for cumulate formation. Can Mineral 33:1011-1022

Maier WD, Eales HV (1997) Correlation within the UG2-Merensky Reef interval of the Western Bushveld Complex, based on geochemical, mineralogical and petrological data. Geological Survey of South Africa Bulletin, vol 120

Maier WD, Barnes S-J, Groves DI (2013) The Bushveld complex, South Africa: formation of platinum-palladium, chrome-and vanadium-rich layers via hydrodynamic sorting of a mobilized cumulate slurry in a large, relatively slowly cooling, subsiding magma chamber. Miner Depos 48:1-56

Maier WD, Karykowski BT, Yang SH (2016) Formation of transgressive anorthosite seams in the Bushveld complex via tectonically induced mobilisation of plagioclase-rich crystal mushes. Geosci Front 7:875-889

Manning CE (1994) The solubility of quartz in $\mathrm{H}_{2} \mathrm{O}$ in the lower crust and upper mantle. Geochim Cosmochim Acta 58:4831-4839

Mathez EA, Kinzler RJ (2017) Metasomatic chromitite seams in the Bushveld and Rum layered intrusions. Elements 13:397-402

McBirney AR, Noyes RM (1979) Crystallization and layering in the Skaergaard intrusion. J Petrol 20:487-554

Meurer WP, Klaber SA, Boudreau AE (1997) Discordant bodies from olivine-bearing zones III and IV of the Stillwater complex, Montana-evidence for post-cumulus fluid migration in layered intrusions. Contrib Mineral Petrol 130:81-92

Mungall JE, Kamo SL, McQuade S (2016) U-Pb geochronology documents out-of-sequence emplacement of ultramafic layers in the Bushveld Igneous complex of South Africa. Nat Commun 7:1-13

Newton RC, Manning CE (2000) Quartz solubility in $\mathrm{H}_{2} \mathrm{O}-\mathrm{NaCl}$ and $\mathrm{H}_{2} \mathrm{O}-\mathrm{CO}_{2}$ solutions at deep crust-upper mantle pressures and temperatures: 2-15 kbar and 500-900 C. Geochim Cosmochim Acta 64:2993-3005

Pronost J, Harris C, Pin C (2008) Relationship between footwall composition, crustal contamination, and fluid-rock interaction in the Platreef, Bushveld Complex, South Africa. Miner Depos 43:825-848

Raedeke LD, McCallum IS (1984) Investigations in the Stillwater complex: part II. Petrology and petrogenesis of the ultramafic series. J Petrol 25:395-420

Robb SJ, Mungall JE (2020) Testing emplacement models for the Rustenburg Layered Suite of the Bushveld complex with numerical heat flow models and plagioclase geospeedometry. Earth Planet Sci Lett 534:116084

Salpas PA, Haskin LA, McCallum IS (1983) Stillwater anorthosites: a lunar analog? In: Proceedings of the 14th lunar and planetary science conference, Part 1. J Geophys Res 88(Suppl):B27-B39

Schiffries CM (1982) The petrogenesis of a platiniferous dunite pipe in the Bushveld complex; infiltration metasomatism by a chloride solution. Econ Geol 77(6):1439-1453
Scholten L, Watenphul A, Beermann O, Testemale D, Ames D, Schmidt C (2018) Nickel and platinum in high-temperature $\mathrm{H}_{2} \mathrm{O}$ $+\mathrm{HCl}$ fluids: implications for hydrothermal mobilization. Geochim Cosmochim Acta 224:187-199

Scoates JS, Mitchell JN (2000) The evolution of troctolitic and high Al basaltic magmas in Proterozoic anorthosite plutonic suites and implications for the Voisey's Bay massive $\mathrm{Ni}-\mathrm{Cu}$ sulfide deposit. Econ Geol 95:677-701

Scoon RN, Costin G (2018) Chemistry, morphology and origin of magmatic-reaction chromite stringers associated with anorthosite in the upper critical zone at Winnaarshoek, Eastern Limb of the Bushveld complex. J Petrol 59:1551-1578

Sharpe MR (1981) The chronology of magma influxes to the eastern compartment of the Bushveld complex, as exemplified by its marginal border group. J Geol Soc Lond 138:307-326

Sisson TW, Grove TL (1993) Experimental investigations of the role of $\mathrm{H}_{2} \mathrm{O}$ in calc-alkaline differentiation and subduction zone magmatism. Contrib Mineral Petrol 113:143-166

Sonnenthal EL (1992) Geochemistry of dendritic anorthosites and associated pegmatites in the Skaergaard intrusion, East Greenland: evidence for metasomatism by a chlorine-rich fluid. J Volcanol Geotherm Res 52:209-230

Teigler B, Eales HV (1996) The lower and critical zones of the western limb of the Bushveld complex, as indicated by the Nooitgedacht boreholes. Geological Survey of South Africa Bulletin, vol 111

Turner SP, Stüwe K (1992) Low-pressure corona textures between olivine and plagioclase in unmetamorphosed gabbros from Black Hill, South Australia. Mineral Mag 56:503-509

Vermaak CF (1976) The Merensky Reef-thoughts on its environment and genesis. Econ Geol 71:1270-1298

Von Gruenewaldt G (1979) A review of some recent concepts of the Bushveld complex, with particular reference to sulfide mineralization. Can Mineral 17:233-256

Wager LR, Brown GM (1967) Layered igneous rocks. Oliver and Boyd, Edinburgh, p 588

Wager LR, Brown GM, Wadsworth WJ (1960) Types of igneous cumulates. J Petrol 1:73-85

Yang SH, Maier WD, Lahaye Y, O’Brien H (2013) Strontium isotope disequilibrium of plagioclase in the upper critical zone of the Bushveld complex: evidence for mixing of crystal slurries. Contrib Mineral Petrol 166:959-974

Zhitova LM, Kinnaird JA, Gora MP, Shevkoa EP (2016) Magmatogene fluids of metal-bearing Reefs in the Bushveld complex, South Africa: based on research data on fluid inclusions in Quartz. Geol Ore Depos 58:58-81

Publisher's Note Springer Nature remains neutral with regard to jurisdictional claims in published maps and institutional affiliations. 